\title{
PROBLEMS OF MANAGEMENT OF GRASSLAND UNDER LOW RAIN- FALL CONDITIONS IN THE UNION OF SOUTH AFRICA
}

By J. D. SCOTT, Professor of Pasture Management and Soil Conservation, University of Natal, South Africa.

It was originally suggested that this paper should deal with problems associated with the management of grazings under low rainfall conditions and the title submitted was "Problems of management of grassland under low rainfall conditions in South Africa." It was decided, however, that as much of the veld under low rainfall conditions was not grassland, it would be better to deal with the main veld regions in areas of low rainfall. The next decision to be made was what was to be considered as "low rainfall" and, after a careful study of the main veld types, it was decided that low rainfall areas would include those which enjoyed an annual rainfall of 20 inches or less.

Such areas occupy approximately 60 per cent of the Union of South Africa and embrace nearly 40 major vegetation types which cannot be treated separately here. For the purpose of this paper, the low rainfall areas have been classified into six broad ecological regions which together comprise a total area of approximately 265,000 square miles. In this classification various vegetal regions with similar characteristics and problems have been grouped together.

The six main regions are:

1. The Open, Sweet Grassveld.

2. The Semi-arid Karoo of Summer Rainfall.

3. 'The Arid Karoo of Summer Rainfall.

4. The Winter Rainfall Karoo.

5. The Kalahari Thorn and Bushveld.

6. The Sweet Veld of the Northern Transvaal.

It must be realised that, for the sake of convenience in the preparation of this paper, some vegetal NOTE.-Veld in South Africa may be defined as natural vegetation other than
forest which has not been disturbed by cultivation. 
regions have been included in the main groups which do not rightly belong to any of them but none of which was large enough to include separately.

\section{The Open, Sweet Grassveld}

This region occupies approximately 30,000 square miles. The mean annual rainfall, which occurs in sum-

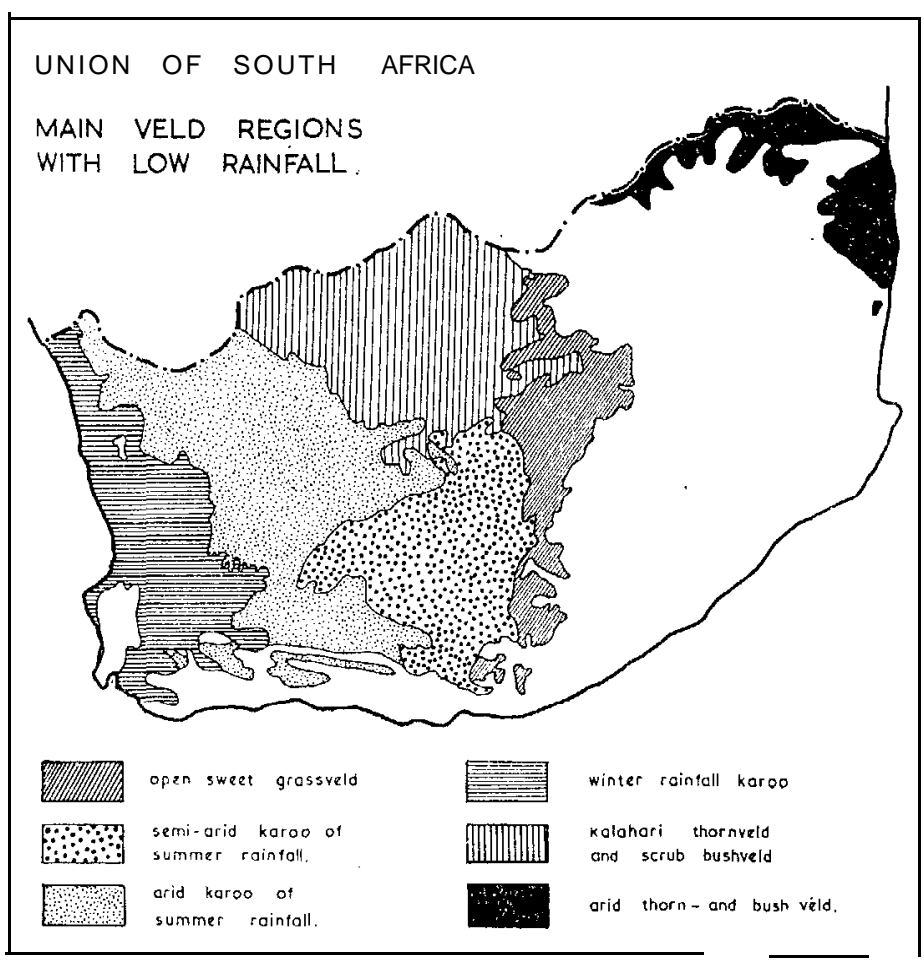

mer, is 17 to 25in. Most of the rain falls in heavy storms, many of which occur in the late summer period from January to April.

The topography of the region varies from mountain ranges to broad and narrow valleys and extensive plains. The soils also vary greatly.

Generally the rainfall is too low for any cropping, but high enough to tempt the plough, with the result that the region is defaced by numerous old, impoverished, and eroding dry lands scattered throughout. One of the problems of this region is to discover how these old lands can be revegetated.

This Sweet Grassveld region was formerly clothed 
by a good growth of short grasses among which the most important were Themeda triandra and Tetrachne dregii. The term "Sweet" refers to the fact that the majority of the grasses were palatable even when dry. Much of the original Grassveld has been replaced by Karoo and little of the remainder is in really good condition. Acacia karoo has also invaded the dry, eroding watercourses and spread into the adjacent uplands where it competes further with the grasses.

Research has shown that there are two critical seasons of growth during which continuous grazing does damage to the Sweet Grassveld. These are the late summer and the spring and early summer respectively. For the improvement of this grassveld, $i$ " has been found essential to provide it with a late summer rest, followed by a rest during the spring and early summer the following season. This elementary principle has been incorporated in several simple systems of grazing rotation, of which two are as follows:

\begin{tabular}{l|l|l}
\hline Years & Camp A & \multicolumn{1}{c}{ Camp B } \\
\hline 1st & $\begin{array}{l}\text { Graze spring; early sum- } \\
\text { mer, and winter. Rest late } \\
\text { summer and autumn. }\end{array}$ & $\begin{array}{l}\text { Graze late summer and } \\
\text { autumn. Rest spring, early } \\
\text { summer, and winter. }\end{array}$ \\
\hline 2nd & $\begin{array}{l}\text { Graze la e summer and } \\
\text { autumn. Rest spring, early } \\
\text { summer, and winter. }\end{array}$ & $\begin{array}{l}\text { Graze spring, early sum- } \\
\text { mer, and winter. Rest late } \\
\text { summer and autumn. }\end{array}$ \\
\hline
\end{tabular}

\begin{tabular}{|c|c|c|c|}
\hline \multirow{2}{*}{ Years } & \multicolumn{3}{|c|}{ Camps } \\
\hline & A. & B. & C. \\
\hline $1 \mathrm{st}$ & $\begin{array}{l}\text { Graze spring and } \\
\text { early winter. }\end{array}$ & $\begin{array}{l}\text { Graze early sum } \\
\text { mer and late } \\
\text { winter. }\end{array}$ & $\begin{array}{l}\text { Graze late sum- } \\
\text { mer and autumn. }\end{array}$ \\
\hline$\overline{2 n d}$ & $\begin{array}{l}\text { Graze early sum- } \\
\text { mer and late } \\
\text { winter. }\end{array}$ & $\begin{array}{l}\text { Graze late sum- } \\
\text { mer and autumn. }\end{array}$ & $\begin{array}{l}\text { Graze spring and } \\
\text { early winter. }\end{array}$ \\
\hline 3rd & $\begin{array}{l}\text { Graze late sum- } \\
\text { mer and autumn. }\end{array}$ & $\begin{array}{l}\text { Graze spring and } \\
\text { early minter. }\end{array}$ & $\begin{array}{l}\text { Graze early sum- } \\
\text { mer and late } \\
\text { w in t e r. }\end{array}$ \\
\hline
\end{tabular}

These systems are suitable for either a herd of cattle or a mixed group of cattle and sheep grazing together. It is not suitable for sheep alone and, up to 
the present, it has not been possible to devise a grazing system for sheep alone that is beneficial to both veld and livestock.

\section{The Semi-arid Karoo of Summer Rainfall}

This region occupies approximately 43,000 square miles. Its climate generally is similar to that of the Sweet Grassveld region but drier and more extreme, both in respect of rainfall and temperatures and also of desiccating winds. The mean annual rainfall varies from $8 \mathrm{in}$. in the west to $20 \mathrm{in}$. in the east.

The topography is varied with the northern and western portions comprising extensive plains broken by occasional hills and ridges while the southern and eastern portions are more mountainous and broken. Soils vary widely with topography, but a significant feature of the region in general is the large number of fairly extensive alluvial flood plains or "vleis" that occur throughout it.

A fair amount of irrigation is practised, mainly for production of fodder crops, but dryland crop production is not possible.

The vegetation of the region is characterised in general by an admixture of small xerophytic shrubs and various xerophytic grasses. In the west the extensive plains are occupied largely by dwarf shrubs and some desert grasses. In the south and south-east succulent plants become common; in the north-west and south-east, too, small xerophytic trees occur, while eastwards grasses increase in prominence till they merge into the Sweet Grassveld. Many of the mountain ranges are still covered by 'grass.

Much of this region was formerly Sweet Grassveld, but it was invaded by the Karoo vegetation with serious consequences to soil and water resources. The mountain ranges have also been severely encroached upon by worthless scrub. Soil erosion is very serious throughout the region, particularly on the deep'alluvial soils. Research work has shown that the depleted flood plains may be rapidly restored to provide excellent winter pasturage by resting in summer and the use of mechanical structures where necessary. Similarly, on mountain slopes where remnants of topsoil remain, the former grass cover can be restored by the application of one of the systems of management described for the Sweet Grassveld. Where the soil has disappeared reclamation is a difficult task.

Considerable difficulties are encountered on the 
dry plains. Much of the topsoil has been lost through erosion and most of the grasses found there today consist of pioneer annuals and short-lived perennials. Among these are many species of the genus Aristida and their awned seeds cause considerable harm to woolled sheep. Many Karoo shrubs occur and, although they are valuable fodder plants, they are incapable of conserving the soil against erosion.

Attempts to regenerate grass have not been very successful, for when, in favourable seasons, such grasses have ousted the Karoo bushes, they themselves have disappeared during droughts, leaving areas completely devoid of vegetation. The investigations have shown that the only practical policy is to attempt to develop the best and densest mixture of both grass and Karoo bush while preventing the grass from ousting the bush. The stock usually live on the grass in summer and the bushes in winter after the grass has frosted dry. A simple method of management which has proved highly successful in achieving this is as f 0 o 1 l 1 o $\quad$ w $s$ :

\begin{tabular}{l|l|l}
\hline \multicolumn{1}{|c|}{ Camp A } & \multicolumn{1}{c}{ Camp B } \\
\hline 1st & $\begin{array}{l}\text { Graze spring, autumn and } \\
\text { late winter. Rest summer, } \\
\text { and early winter. }\end{array}$ & $\begin{array}{l}\text { Graze summer and early } \\
\text { winter. Rest spring, aut- } \\
\text { umn, and late winter. }\end{array}$ \\
\hline 2nd & $\begin{array}{l}\text { Graze summer and early } \\
\text { winter. Rest spring, aut- } \\
\text { umn, and late winter. }\end{array}$ & $\begin{array}{l}\text { Graze spring, autumn, } \\
\text { and late winter. Rest sum- } \\
\text { mer and early winter. }\end{array}$ \\
\hline
\end{tabular}

Heavy, continuous grazing usually results in diminution of grass and increase of bush. It has been found also that there is a certain amount of selective grazing of the shrubs, of which different species occur on different soil types. Consequently when dividing a farm into camps for the purpose of grazing management it is usually necessary to follow the broader topographical veld types to ensure the uniform utilisation of the vegetation over the whole of each camp.

\section{The Arid Karoo of Summer Rainfall}

This area, 75,000 square miles in extent, is characterised by its low, erratic rainfall, high summer temperatures, and desert soils and vegetation. The rainfall varies from 4 to $8 \mathrm{in}$. on the plains to $14 \mathrm{in}$. in the mountains. The vegetation of the vast arid plains of this region is composed of dwarf xerophytic shrubs and 
desert grasses while the mountains have taller shrubs, Karoo bushes, succulents, and various grasses. The desert grasses maintain their feeding value even when desiccated.

The main problem of this area is the denudation of vegetal cover due to overgrazing. When protected from grazing the veld shows remarkable powers of recuperation and develops a good cover of desert grasses.

Up to the present very little research has been done in this region, but a method of grazing management which has been advocated with promising results allows for the resting in turn of one-third of the veld for a full 12 months at a time while the other twothirds are grazed according to circumstances and requirements.

\section{The Winter Rainfall Karoo}

This region, which occupies approximately 30,000 square miles, has highly varied topography and the mean annual rainfall varies from 4 to 14 in. The summer is dry.

This is a problem region about which little scientific information is available. Most of the area is badly eroded and some areas have been reduced to virtual' desert.

\section{The Kalahari Thorn and Bush Veld}

This is a very large area of approximately 62,000 square miles. The rainfall, which occurs in the summer, ranges from 15 to 20in. per annum. The soils are sandy for the most part. In the southern part of the region the vegetation consists of shrubs, many of which are edible, and sweet grasses which retain their palatability during the dry season.

In the northern part of the region the vegetation is characterised by fairly tall trees giving a parkland. appearance to the country. The grasses are also nutritious when dry.

Much of this country has been overgrazed and, had 'it not been for shortage of water, it might have been in a far worse state.

Under continuous grazing the veld deteriorates and the shrubs tend to increase. Rests at intervals of two or three years in spring and early summer and in autumn are essential for the maintenance of a good grass cover. A system of management which gives good results here is that recommended for the Sweet Thornveld of the Northern Transvaal which is described next. 


\section{The Sweet Thorn and Bushveld of the Northern Transvaal}

This area of about 20,000 square miles comprises several arid veld types. It has a rainfall of 8 to $12 \mathrm{in}$. most of which falls in the summer; the rains in. spring and early summer are very erratic. In some parts the vegetation consists of deciduous bush while, in other parts, it is characterised by Thorn Bush composed of various acacia species. The grasses are typical of low rainfall areas, being palatable and nutritious when dry. Much overgrazing has taken place, however, with the result that many annual grasses occur and much encroachment of bush has taken place. The encroaching bush competes with the grasses for moisture and light and, when encroachment becomes severe, the soil is denuded of grass cover.

With the erratic rainfall in the early summer and the fact that many of the grasses are annuals, heavy grazing in the early summer is most deleterious. Regular rests at this season are necessary, as are rests in the autumn for the building up of root reserves. The rainfall is so erratic that droughts are common and any system of veld management must allow not only for regular rests in early summer and in autumn, but

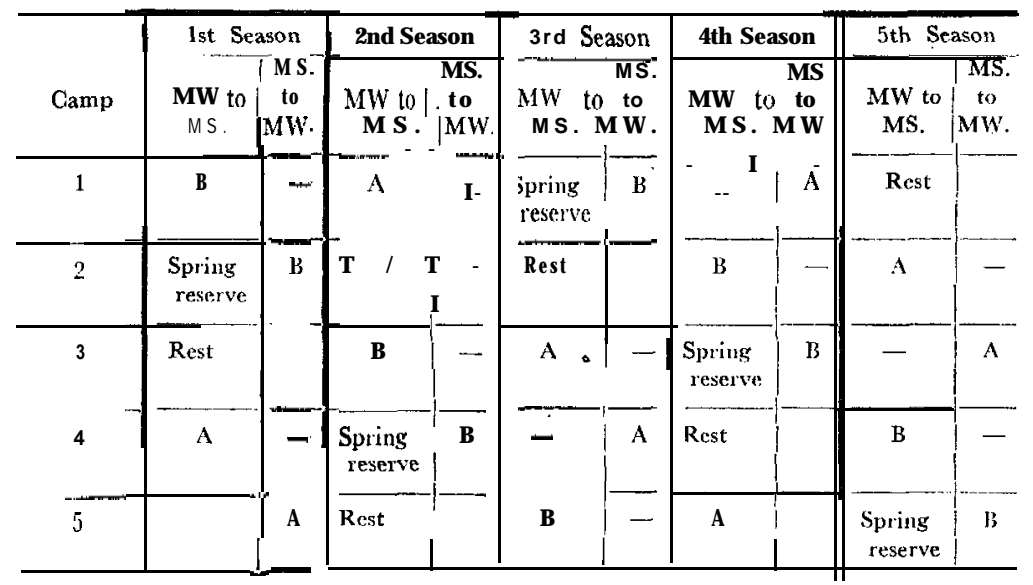

Here "A" and "B" indicate two separate herds of stock.

"MW" = mid-winter, "MS" = midsummer, Reserve indicates a camp which is being rested for a. whole year-midsummer to "midsummer-and which may be used for grazing in spring in seasons of delayed growth. "Rest" indicates camps which are rested from mid-winter to mid-winter and are completely rested with no grazing at all during that period. 
also for reserves for periods of dsought. A system of five camps to two herds, so managed that only 40 per cent of the area is grazed at any one time, has been applied with great success in co-operative experiments with farmers over an area of 300 square miles. This system, which allows for grazing of camps from midwinter to midsummer and from midsummer to midwinter, is shown in table on previous page.

Each camp in this system is rested either in the early or late season each year and has, in addition, a complete growing season's rest once in 5 years. This system has led to recovery of denuded veld with much improved production on all veld managed in this way.

A serious problem as mentioned earlier is the encroachment of bush at the expense of the grass cover. Veld burning may control spread of bush in early stages but cannot destroy older dense bush. Mechanical methods of clearing are expensive, so chemical methods are being investigated. Paraffin or diesoline is sometimes very effective, but results cannot be guaranteed, and so further work with selective poisons is being continued.

\section{Discussion}

The systems of veld management advocated for the various regions all allow for rest at some part of the growing season, based on a knowledge of the physiology and ecology of the plants. In most of these low rainfall areas the early part of the growing season is critical because the rainfall is so extremely erratic at this time: Occasional showers of rain may lead to the germination of many annual grasses which may dry off in subsequent droughts without seeding; Continuous grazing removes these plants. Perennial grasses draw on root reserves for growth after the first rains and may then dry off, thus weakening the plants. Rests in the early season are thus essential at regular intervals. During the late summer and autumn, translocation of reserves to the roots takes place, and thus it is necessary to rest the veld at this time at regular intervals too.

Although many of the earlier systems of grazing management were evolved by trial and error, it was found that those which were successful all complied with these requirements. It is therefore claimed that the proper basis for grazing management in any area should be the resting of the veld at regular intervals and the times at which the rests are given should depend on a knowledge of the ecology and physiology of 
the plants. In other parts of the world it has been claimed that continuous grazing gives the best results provided that the carrying capacity of the grassland is correctly adjusted. This definitely does not hold for the regions described in this paper and therefore rotational or deferred systems of grazing management are advocated.

\section{Literature Cited}

The following four publications have been freely consulted and quoted throughout:

Acocks, J. P. H.: Veld Types of South Africa. Bot. Survey of S.A. Memoir No. 28.

Irvine, L. O. F. : Quinquennial Report of Toowoomba Research Stn. M.S.

Scott, J. D.: Management of Grassland in the Sourveld and Bushveld areas of the Union. Report prepared for SARCCUS Conference. M.S.

Tidmarsh, C. E. M.: Grazing Management in the Karoo and Open, Sweet Grassveld Regions. Report prepared for SARCCUS Conference. M.S.

\section{Summary}

The low rainfall areas of the Union with $20 \mathrm{in}$ or less annual rainfall can be divided into 6 very large areas in which erosion and veld deterioration are rife.

Continuous grazing has been shown to lead to deterioration, so methods of management, allowing for periods of rest during stages of critical growth, have been evolved.

\section{DISCUSSION}

Q. Is the scrub which is the dominant plant, leguminous, and if not has any work been done on these plants?

A. Most of the plants are composites. Work has been done to try to introduce leguminous plants but the long dry winter kills most of the known legumes.

Q. What is the method by which you start out to spell 60 per cent of the area? Where do you carry the animals when you start spelling?

A. We concentrated the stock for the four to six months' growing season, then moved them to the other section for the next six months. The first grazing might have been rather heavy. We started, not in the spring? but in midsummer so that when the first rest was given it was a latesummer rest. The concentration of stock in the autumn was on land with a certain amount of cover.

Q . What is the story about water? I noticed a windmill and waterholes. Is there no prospect of using water for irrigation?

A. There is some irrigation carried out in certain parts of the arid areas but not very much in comparison with the size of the area because a great deal of water does not 
come from permanent rivers. Often there is no water available. A great deal has to be pumped from great depths for livestock and cannot be used for irrigation because there is not enough of it. In any case it would be too expensive for irrigation.

Q. What are the mechanics by which grazing with cattle reduces the Karoo bush and lets the grass get away? What is the ecology of the grazing?

A. I cannot explain. We have found that where we have introduced cattle we have achieved better results. Briefly the issue is to keep the grass growing. Sheep graze small areas which they graze in to the ground.

Q. Have you seen any part of New Zealand where similar conditions exist? Is Central Otago like South Africa?

A. It is similar in places but the distribution of the rainfall is different. I must stress that 30 per cent of South Africa does not look like what I have shown you. 